\title{
Assessment of Novel C-4 Methylated Tetraketide by HPLC-SPE-TT in Saccharicola sp., an Endophytic Fungus in Eugenia jambolana Lam.
}

\author{
Maiara S. Borges, ${ }^{a}$ Carolina R. Biasetto, ${ }^{a}$ Vanessa M. Chapla,${ }^{b}$ Samad N. Ebrahimi, ${ }^{c}$ \\ Mayra F. Costa, ${ }^{a}$ Vanderlan S. Bolzani ${ }^{a}$ and Angela R. Araujo ${ }^{\circledR}, a$ \\ ${ }^{a}$ Instituto de Química, Universidade Estadual Paulista (Unesp), 14800-060 Araraquara-SP, Brazil \\ ${ }^{b}$ Química Ambiental, Universidade Federal do Tocantins (UFT), 77402-970 Gurupi-TO, Brazil \\ ${ }^{c}$ Department of Phytochemistry, Medicinal Plants and Drugs Research Institute, \\ Shahid Beheshti University, 1983963113 Evin, Tehran, Iran
}

\begin{abstract}
A new compound named methyl $(6 S, 7 S, 2 E, 4 E)$-6,7-dihydroxy-4,6-dimethyl octanoate was isolated from Saccharicola sp. using high performance liquid chromatography-solid phase extraction-transfer tube (HPLC-SPE-TT), together with four known compounds, fusaric acid, trans-4-hydroxymellein, thymidine and adenosine. Saccharicola sp. was isolated from the stems of Eugenia jambolana Lam. (Myrtaceae) as endophytic fungus. The structure of this novel substance was established based on its spectroscopic data, including ${ }^{1} \mathrm{H}$ and ${ }^{13} \mathrm{C}$ nuclear magnetic resonance (NMR), 2D NMR techniques and high-resolution electrospray ionization mass spectrometry (HR-ESI-MS). This paper deals with the first report of its kind on this compound in Saccharicola sp.
\end{abstract}

Keywords: endophytic fungus, Eugenia jambolana Lam., Saccharicola sp.

\section{Introduction}

The scientific community has focused its attention on the secondary metabolites from the fungi kingdom for the discovery of numerous biologically active compounds, including antifungal, new antibiotics, chemotherapeutic agents and agrochemicals. Endophytic fungi are capable of producing a range of bioactive secondary metabolites with a structural diversity, being possible to apply them in medicine and agriculture. ${ }^{1-3}$

The plant species Eugenia jambolana Lam. (Myrtaceae) has been exploited chemically and biologically as a result of its popular use besides the fact that it presents several pharmacological activities. ${ }^{4}$ Dametto et al..$^{5}$ demonstrated the extracts and fractions from E. jambolana are promising as prototypes of new chemopreventive compounds. The study of endophytic fungi, associated with this species, unfolds a remarkably promising strategic window in the identification of potentially bioactive substances. This plant species exhibits a wide range of endophytes, among them Saccharicola sp. was selected for chemical study owing to the activities it presented against phytopathogenic fungi $C$. sphaerospermum, apart from its antioxidant and anticholinesterase activities. ${ }^{6}$ Preliminary studies of Saccharicola sp. presented unprecedented oxygenated cyclohexanoids. ${ }^{7}$ These compounds have stimulated myriad works of synthesis as result of their reported antifungal, antibacterial and antitumor activities. ${ }^{8}$ Zhao et al. ${ }^{9}$ showed new isoprenylated cyclohexanols, which were isolated from the sponge-associated fungus Truncatella angustata. Besides the truncateol $\mathrm{M}$ exhibited potent inhibitory effect against influenza-A viral infection. ${ }^{9}$

The present work was aimed at conducting chemical assessment of the endophytic fungus Saccharicola sp. isolated from Eugenia jambolana Lam. Herein we discuss the isolation, structure elucidation of new compound (6S,7S,2E,4E)-6,7-dihydroxy-4,6-dimethyl octanoate (1) and the known compounds mycotoxin fusaric acid, trans-4-hydroxymellein, thymidine and adenosine (2-5). The absolute configuration of compound $\mathbf{1}$ was determined by comparing experimental and calculated electronic circular dichroism (ECD) spectroscopy data.

*e-mail: angela.araujo@unesp.br 


\section{Experimental}

\section{General experimental procedures}

The compound 1 was isolated using high performance liquid chromatography-solid phase extraction-transfer tube (HPLC-SPE-TT) comprising a solid phase extractor (SPE) Bruker/Spark Prospekt II as an interface between an HPLC in the analytical mode, an Agilent 1260 infinity series HPLC (HP1260 infinity, Agilent, USA) with diode array ultraviolet detector (DAD) and an automatic nuclear magnetic resonance (NMR) sampler and tracer (TT).

An interface (Bruker) operating in the stop-flow mode was used for the treatment of samples for NMR tubes in a totally automated way. The sample was solubilized in $\mathrm{MeOH}: \mathrm{H}_{2} \mathrm{O}$ (90:10) and cleaned using RP-18 silica cartridges coupled to Millipore ${ }^{\circledR}$ membrane $(0.2 \mu \mathrm{m})$. At the end of this procedure, the sample $\left(10 \mathrm{mg} \mathrm{mL}^{-1}\right)$ was stored in a vial. The system employed for HPLC-SPE-TT analysis was a Luna Phenomenex octadecyl silane (RP-18) analytical column (Phenomenex Luna $250 \times 4.60 \mathrm{~mm}, 5 \mu \mathrm{m}$, $100 \AA$ ). Mass spectra were acquired by quadrupole time-offlight (Q-TOF) Bruker MaXis Impact mass spectrometer using electrospray ionization mass spectrometry (ESI-MS) and $\mathrm{MeOH}: \mathrm{H}_{2} \mathrm{O}(1: 1)$ as the eluent. Infrared (IR) spectra were recorded on a Jasco FTIR-4600 series spectrometer equipment, while the FTIR spectrum was recorded with 128 scans per spectrum with a resolution of $4 \mathrm{~cm}^{-1}$. ECD and UV spectra were obtained on a JASCO J-815 spectrometer. Optical rotations were measured using a PerkinElmer polarimeter equipped with a sodium lamp operating at $30^{\circ} \mathrm{C}$ and a sample cell volume of $1 \mathrm{~mL}$ using methanol $(\mathrm{MeOH})$ as solvent.

\section{Plant material}

The ripe fruits as leaves of Eugenia jambolana were collected on March 27, 2008 in a square in the city of Araraquara, state of São Paulo. The specie was identified by Dra Maria Inês Cordeiro and a voucher specimen No. SP 454124 has been deposited in the Herbarium "Maria Eneida Kauffmann", of the Botanic Garden of São Paulo, Brazil.

Growth of Saccharicola sp., extraction and isolation of the compounds 1-5

The endophytic fungus Saccharicola sp. was inoculated into three Petri dishes containing PDA (potato dextrose agar) and incubated for 10 days at $25^{\circ} \mathrm{C}$.

To obtain the crude extract in Czapek, one third of mycelium from each Petri dish was inoculated into 40 Erlenmeyer flasks $(500 \mathrm{~mL})$ containing $300 \mathrm{~mL}$ of liquid medium (Czapek). Saccharicola sp. was incubated for 28 days in static mode at $25{ }^{\circ} \mathrm{C}$. After this time, the accumulated biomass was separated from the aqueous medium by filtration, and then the filtrate was subjected to liquid-liquid partition with ethyl acetate $(\mathrm{EtOAc}, 3 \times 2.7 \mathrm{~L})$. The EtOAc fraction was evaporated to dryness, to give $350.0 \mathrm{mg}$ of crude extract.

To obtain the crude extract in corn, Saccharicola sp. was cultivated in 9 Erlenmeyer flasks $(500 \mathrm{~mL})$, each containing $90 \mathrm{~g}$ of corn and $75.0 \mathrm{~mL}$ of distilled water. The medium was autoclaved three times (in three consecutive days) at $121{ }^{\circ} \mathrm{C}$ for $20 \mathrm{~min}$. Following sterilization, the medium was inoculated with the endophyte and incubated while stationary at $25^{\circ} \mathrm{C}$ for 21 days. At the end of the incubation period, the cultures were combined, ground and extracted with EtOAc $(5 \times 200 \mathrm{~mL})$. The solvent was evaporated, yielding a crude EtOAc extract (5.16 g) which was portioned with $\mathrm{H}_{2} \mathrm{O}(3 \times 5 \mathrm{~mL})$. The EtOAc extract was dissolved in acetonitrile $\left(\mathrm{CH}_{3} \mathrm{CN}\right)$ and defatted with hexane by liquid partitioning. The $\mathrm{CH}_{3} \mathrm{CN}$ fraction was evaporated to yield $540.0 \mathrm{mg}$ of crude extract.

For the isolation of compounds $\mathbf{1}$ and $\mathbf{2}$ the EtOAc crude extract $(250.0 \mathrm{mg}$ ) was fractionated in SPE cartridge (solid phase extraction), and a total of 6 fractions were obtained. The fraction 3 was subjected to study via the HPLC-SPE-TT technique using an RP-C ${ }_{18}$ column, eluted by $\mathrm{H}_{2} \mathrm{O}: \mathrm{MeOH}(90: 10-0: 100)$ in $40 \mathrm{~min}$ in the analytical mode, at flow rate of $0.8 \mathrm{~mL} \mathrm{~min}^{-1}, \lambda=254 \mathrm{~nm}$ and $30 \mu \mathrm{L}$ injection volume, to give compound $1(0.5 \mathrm{mg})$. The fraction 1 was analyzed by HPLC using an RP- $\mathrm{C}_{18}$ column in the semi-preparative mode and as eluent a gradient of $\mathrm{H}_{2} \mathrm{O}: \mathrm{CH}_{3} \mathrm{CN}(90: 10-0: 100)$ in $36 \mathrm{~min}$, flow rate of $3.5 \mathrm{~mL} \mathrm{~min}^{-1}, \lambda=254 \mathrm{~nm}$ and injection volume of $150 \mu \mathrm{L}$, to give compound 2 ( $0.9 \mathrm{mg})$.

The $\mathrm{CH}_{3} \mathrm{CN}$ fraction $(540.0 \mathrm{mg}$ ) from the corn culture medium was subjected to HPLC using RP-C ${ }_{18}$ column in the semi-preparative mode and as eluent a gradient of $\mathrm{H}_{2} \mathrm{O}: \mathrm{CH}_{3} \mathrm{CN}(90: 10-0: 100)$ in $36 \mathrm{~min}$, flow rate of $3.5 \mathrm{~mL} \mathrm{~min}^{-1}, \lambda=254 \mathrm{~nm}$ and injection volume of $150 \mu \mathrm{L}$ resulting in the isolation of the compound $3(0.8 \mathrm{mg})$.

To obtain compounds $\mathbf{4}$ and $\mathbf{5}$, an aqueous fraction was added to a $20.0 \times 2.5 \mathrm{~cm}$ glass column packed with approximately $20.0 \mathrm{~g}$ Amberlite XAD-16N resin previously hydrated with water. Approximately $200.0 \mathrm{mg}$ of the aqueous fraction was diluted in $100 \%$ water and added to the column. Once loaded into the aqueous resin fraction, it was fractionated with $600 \mathrm{~mL}$ of water followed by $300 \mathrm{~mL}$ of $100 \%$ methanol. The methanol fraction $(80.0 \mathrm{mg})$ was collected and concentrated by evaporation at low pressure. 
This $\mathrm{CH}_{3} \mathrm{OH}$ fraction was analyzed by HPLC using RP- $\mathrm{C}_{18}$ column in the semi-preparative mode, and as eluent an isocratic system of $\mathrm{H}_{2} \mathrm{O}: \mathrm{CH}_{3} \mathrm{OH}$ (90:10) in 36 min in a flow rate of $3.5 \mathrm{~mL} \mathrm{~min}^{-1}$ and $\lambda=254 \mathrm{~nm}$, resulting in the isolation of thymidine (4) $(1.5 \mathrm{mg})$ and adenosine (5) (1.2 mg).

\section{Computational properties}

Conformational analyses for possible stereoisomers of compound 1 were carried out using MacroModel 9.1 software ${ }^{10}$ by applying OPLS-3 force field in $\mathrm{H}_{2} \mathrm{O}$. The conformers in $3 \mathrm{kcal} \mathrm{mol}^{-1}$ energy window from global minima were selected and subjected for geometrical optimization using the density function theory (DFT) with the CAM-B3LYP functional and the $6-31 \mathrm{G}^{* *}$ basis-set as implemented with the Gaussian 09 program package. ${ }^{11}$ Vibrational analysis was performed at the same level to confirm stability of the minima. Time-dependent density functional theory (TDDFT) calculation using CAM-B3LYP/6-31G** basis set in the $\mathrm{MeOH}$ using the self-consistent reaction field (SCRF) method with the conductor-like polarizable calculation model (CPCM) was employed to calculate excitation energy (denoted by wavelength in $\mathrm{nm}$ ) and rotatory strength in dipole velocity $\left(\mathrm{R}_{\text {vel }}\right)$ and dipole length $\left(\mathrm{R}_{\text {len }}\right)$ forms. ECD curves were calculated based on rotatory strengths using half bandwidth of $0.3 \mathrm{eV}$ using SpecDis version 1.61. ${ }^{12}$
Methyl (6S,7S,2E,4E)-6,7-dihydroxy-4,6-dimethyl octanoate (1)

Colorless yellowish oil; $[\alpha]_{D}^{30}-9.09\left(c 0.0022, \mathrm{CH}_{3} \mathrm{OH}\right)$; HR-ESI-MS m/z $237.1098[\mathrm{M}+\mathrm{Na}]^{+}$calcd. for $\mathrm{C}_{11} \mathrm{H}_{18} \mathrm{O}_{4}$ : 237.1103; UV $\left(\mathrm{CH}_{3} \mathrm{OH}\right) \lambda_{\max } / \mathrm{nm} 264 ;{ }^{1} \mathrm{H} \mathrm{NMR}(600 \mathrm{MHz}$, $\left.\mathrm{CH}_{3} \mathrm{OD}\right) \delta 1.15(\mathrm{~d}, J 6.4 \mathrm{~Hz}, \mathrm{H}-8), 1.33(\mathrm{~s}, \mathrm{H}-9), 2.07$ (s, H-10), 3.66 (q, J 6.4 Hz, H-7), 3.77 (s, H-11), 5,89 (d, $J 15.7 \mathrm{~Hz}, \mathrm{H}-2), 6.00$ (s, H-5), 7.32 (d, $J 15.7 \mathrm{~Hz}, \mathrm{H}-3$ ); ${ }^{13} \mathrm{C}$ NMR (150 MHz, CD $\left.\mathrm{OD}\right) \delta 116.6(\mathrm{C}-2), 152.6(\mathrm{C}-3)$, 136.2 (C-4), 145.7 (C-5), 76.9 (C-6), 75.1 (C-7), 17.7 (C-8), 24.7 (C-9), 13.3 (C-10), 52.1 (C-11).

\section{Results and Discussion}

The Saccharicola sp. extract was subjected to preparative HPLC-SPE-TT which resulted in the new methyl $(6 S, 7 S, 2 E, 4 E)$-6,7-dihydroxy-4,6-dimethyl octanoate (1) and four known compounds: the mycotoxin fusaric acid (2), ${ }^{13,14}$ trans-4-hydroxymellein (3), ${ }^{15}$ thymidine (4) and adenosine (5) ${ }^{16,17}$ (Figure 1).

Compound 1 was isolated as yellowish oil $[\alpha]_{D}^{30}=-9.09$, (c $0.0022, \mathrm{CH}_{3} \mathrm{OH}$ ). Electrospray ionization quadrupole time-of-flight HR-ESI-MS analysis exhibited an ion at $\mathrm{m} / z 237.1098[\mathrm{M}+\mathrm{Na}]^{+}$, establishing the molecular formula as $\mathrm{C}_{11} \mathrm{H}_{18} \mathrm{O}_{4}$ (calcd.: 237.1103) indicating a structure with 3 degrees of unsaturation. The IR spectrum showed the presence of an $\alpha, \beta, \gamma, \delta$-unsaturated methyl ester $\left(1732 \mathrm{~cm}^{-1}\right)$. Analysis of the ${ }^{1} \mathrm{H} N \mathrm{NR}$, correlation spectroscopy (COSY)<smiles>COC(=O)/C=C/C(C)=C/[C@@](C)(O)[C@@H](C)O</smiles><smiles></smiles><smiles>C[C@@H]1OC(=O)c2c(O)cccc2[C@H]1O</smiles>

3<smiles>[3H]C(OCCO)n1cc(C)c(=O)[nH]c1=O</smiles>

4<smiles>Nc1ncnc2c1ncn2[C@H](O)[C@H](O)[C@H](O)CO</smiles>

5

Figure 1. Chemical structures of compounds 1-5, isolated from Saccharicola sp. 
and heteronuclear single quantum coherence (HSQC) spectra revealed a sequence of six hydrogens at $\delta_{\mathrm{H}} 5.89(\mathrm{~d}, 1 \mathrm{H}$, $J 15.7 \mathrm{~Hz}, \mathrm{H}-2), 7.32$ (d, 1H, J $15.7 \mathrm{~Hz}, \mathrm{H}-3), 6.0$ (s, 1H, $\mathrm{H}-5), \delta_{\mathrm{H}} 3.66(\mathrm{q}, 1 \mathrm{H}, J 6.4 \mathrm{~Hz}, \mathrm{H}-7), \delta_{\mathrm{H}} 1.15(\mathrm{~d}, 3 \mathrm{H}, J 6.4 \mathrm{~Hz}$, $\mathrm{H}-8), \delta_{\mathrm{H}} 1.33$ (s, 3H, H-9) (Table 1). The correlation of the $\mathrm{H}-5$ olefinic hydrogen with a methyl in $\delta_{\mathrm{H}} 2.07$ (s, 3H, H-10) was also observed in the COSY spectrum. An unsaturated $\alpha, \beta$, carbon, carbon carbonyl system was confirmed due to hydrogen $\delta_{\mathrm{H}} 3.77$ (s, $\left.3 \mathrm{H}, \mathrm{H}-11\right)$ relating to a methyl ester.

The $E$ configuration of the double bond in C-4 was determined with the base on the nuclear Overhauser effect spectrum (NOESY), which confirmed a neighborhood correlation between a single in $\delta_{\mathrm{H}} 6.00$ and the doublet $\delta_{\mathrm{H}}$ 7.32. The $E$ configuration from double bond in $\mathrm{C}-2$ was attributed due the ${ }^{1} \mathrm{H}-{ }^{1} \mathrm{H}$ couple constant value $J 15.7 \mathrm{~Hz}$. The heteronuclear multiple bond correlation (HMBC) of $\mathrm{H}-2 \leftrightarrow \mathrm{C}-4, \mathrm{H}-3 \leftrightarrow \mathrm{C}-1 / \mathrm{C}-5 / \mathrm{C}-10$,

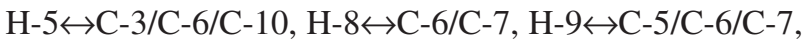
$\mathrm{H}-10 \leftrightarrow \mathrm{C}-3 / \mathrm{C}-4 / \mathrm{C}-5$ and $\mathrm{H}-11 \leftrightarrow \mathrm{C}-1$ allowed us to clearly attribute the substance under consideration to methyl $(6 S, 7 S, 2 E, 4 E)$-6,7-dihydroxy-4,6-dimethyl octanoate (1) (Figure 2). All spectra are provided in Supplementary Information section.

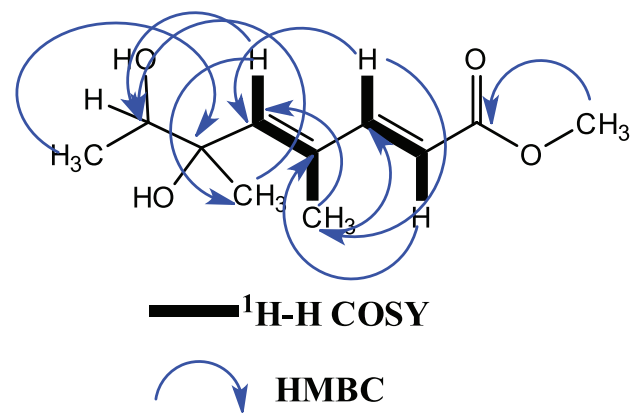

Figure 2. Key COSY and HMBC correlations for compound $\mathbf{1 .}$

Compound 1 possesses two stereogenics centers at C-6 and C-7, therefore four stereoisomers will be assumed namely: $6 S, 7 S ; 6 R, 7 R ; 6 R, 7 S ; 6 S, 7 R$. The experimental ECD data of 1 revealed a sequential positive and negative Cotton effects (CE) at 256 and $220 \mathrm{~nm}$, respectively. These effects are due to $\pi \rightarrow \pi^{*}$ transitions of diene group. The in silico calculation of ECD spectra for all possible stereoisomers are represented in Figure 3. Among the calculated ECD spectra the data from $6 S, 7 \mathrm{~S}$ showed very close similarity with two sequential positive and negative CEs around 255 and $220 \mathrm{~nm}$, where the others showed distinct spectra. Therefore, the absolute configuration of compound $\mathbf{1}$ was determined as methyl $(6 S, 7 S, 2 E, 4 E)$-6,7-dihydroxy4,6-dimethyl octanoate.

Tetraketides with methylation at C-2 and C-6, as well as at C-3 and C-6 are common in nature and are
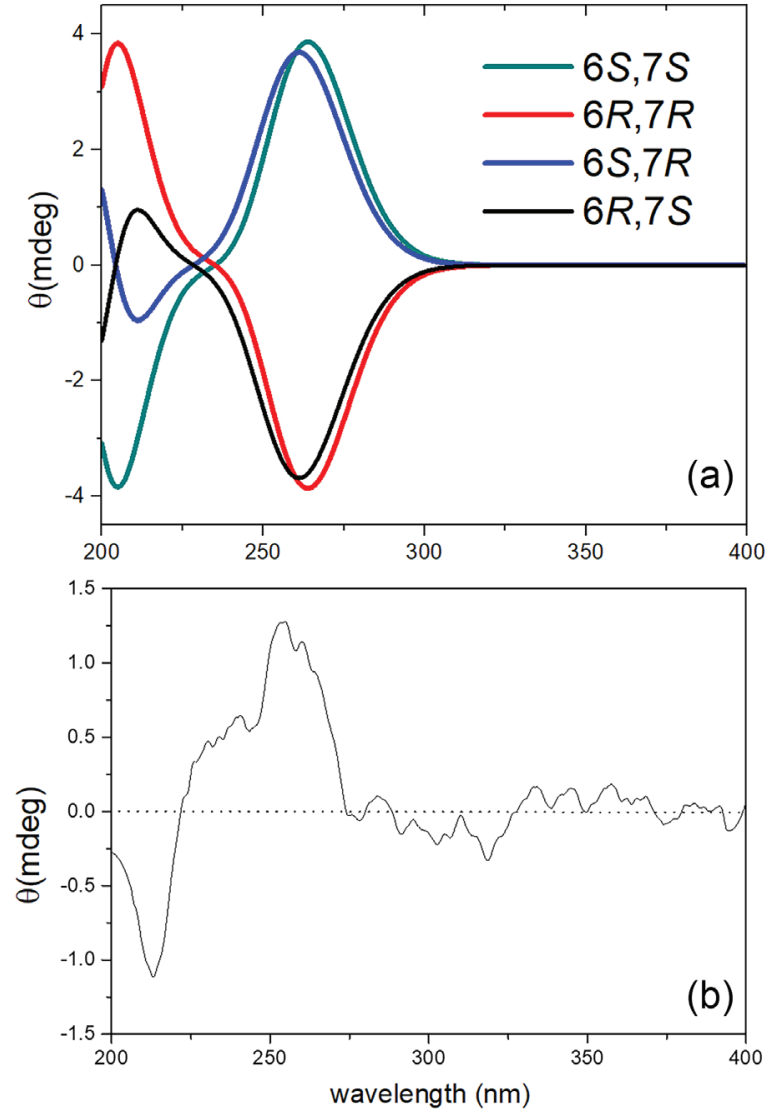

Figure 3. Comparison of of time-dependent density functional theory (TDDFT) calculated spectra for four possible stereoisomers (a) with experimental data of compound $\mathbf{1}$ (b).

found as building blocks in epi-citreodiol, citreoviral, preaurovertin, aurovertin, citreoviridin, citreoviridinols and asteltoxin, citreodiol and 6,7-dihydroxy-3,6-dimethyl octa-2(E),4(E)-dienoic acid with important biological properties. ${ }^{18}$ However, tetraketides with methylation at C-4 and C-6 have been rarely reported in the literature. To the best of our knowledge and as far as the literature is concerned, they are only described as building blocks of coarctatin. ${ }^{19}$

Methyl $(6 S, 7 S, 2 E, 4 E)$-6,7-dihydroxy-4,6-dimethyl octanoate (1) can be obtained by condensing four acetate units with methylation at C-4 and C-6. The base skeleton of this compound can be found in $(R)$ - and $(S)-N, R$ dimethylbenzylamines (DMBA), which are polypeptide macrolides that have apoptotic activity. ${ }^{20}$ Interestingly, reports on compounds similar to 1 suggest that the precursor of its biosynthesis is malonyl-CoA. ${ }^{21}$

The extract of half corn was obtained (without inoculation of the microorganisms), and an evaluation by ${ }^{1} \mathrm{H}$ NMR and HR-ESI-MS was performed aiming to evaluate the presence of substances $\mathbf{4}$ and $\mathbf{5}$ in the control. They were not observed, proving that they were products of biosynthesis of Saccharicola sp. 
Table 1. NMR data for compound $\mathbf{1}$ in $\mathrm{CD}_{3} \mathrm{OD}\left({ }^{1} \mathrm{H}\right.$ NMR at $600 \mathrm{MHz}$ and ${ }^{13} \mathrm{C}$ NMR at $150 \mathrm{MHz}$ )

\begin{tabular}{lcc}
\hline \multirow{2}{*}{ Position } & \multicolumn{2}{c}{1} \\
\cline { 2 - 3 } 1 & $\delta_{\mathrm{H}}$ (multiplicity, J/ Hz) & $\delta_{\mathrm{C}}$ \\
\hline 2 & - & $\mathrm{NO}$ \\
3 & $5.89(\mathrm{~d}, 1.57)$ & 116.6 \\
4 & $7.32(\mathrm{~d}, 15.7)$ & 152.6 \\
5 & - & 136.2 \\
6 & $6.00(\mathrm{~s})$ & 145.7 \\
7 & - & 76.9 \\
8 & $3.66(\mathrm{q}, 6.4)$ & 75.1 \\
9 & $1.15(\mathrm{~d}, 6.4)$ & 17.7 \\
10 & $1.33(\mathrm{~s})$ & 24.7 \\
11 & $2.07(\mathrm{~s})$ & 13.3 \\
\hline
\end{tabular}

NO: not observed; $\delta$ : chemical shift; $J$ : coupling constant.

\section{Conclusions}

Five compounds including a new one were isolated from Saccharicola sp., an endophytic fungus associated with Eugenia jambolana, a vegetal species used in Brazilian traditional medicine. A few reports describe Saccharicola genus chemistry, therefore, this paper could contribute with chemistry data that can help studies about species from Saccharicola genus. The new natural products isolated methyl $(6 S, 7 S, 2 E, 4 E)$-6,7-dihydroxy4,6-dimethyl octanoate (1) belongs to a rarely class of tetraketides compounds with methylation at C-4 and C-6. Reports about similar compounds to 1 suggest that the precursor of its biosynthesis is malonyl-CoA. The studies with endophytic fungi of medicinal plants lead us to obtain unknown metabolites as well metabolites with biological activities, which increase the prospects of using endophytes providing benefits to humanity.

\section{Supplementary Information}

Supplementary information (physical data, ${ }^{1} \mathrm{H}$ and ${ }^{13} \mathrm{C}$ NMR and MS spectra for compounds (1-5)) is available free of charge at http://jbcs.sbq.org.br as PDF file.

\section{Acknowledgments}

The authors would like to sincerely express their gratitude and indebtedness to the Brazilian research funding agencies: Fundação de Amparo à Pesquisa do Estado de São Paulo (CEPID-FAPESP, process No. 2013/07600-3), CNPq (process No. 563286/2010-5), INCT-BioNat (CNPq process 465637/2014-0, FAPESP process 2014/50926-0) for the funds provided in the course of this research.

\section{References}

1. Strobel, G.; Daisy, B.; Microbiol. Mol. Biol. Rev. 2003, 67, 491.

2. Smith, S. A.; Tank, D. C.; Boulanger, L. A.; Bascom-Slack, C. A.; Eisenman, K.; Kingery, D.; Babbs, B.; Fenn, K.; Greene, J. S.; Hann, B. D.; Keehner, J.; Kelley-Swift, E. G.; Kembaiyan, V.; Lee, S. J.; Li, P.; Light, D. Y.; Lin, E. H.; Ma, C.; Moore, E.; Schorn, M. A.; Vekhter, D.; Nunez, P. V.; Strobel, G. A.; Donoghue, M. J.; Strobel, S. A.; PLoS One 2008, 3, e3052.

3. Mitchell, A. M.; Strobel, G. A.; Moore, E.; Robison, R.; Sears, J.; Microbiology 2010, 156, 270.

4. Srivastava, S.; Chandra, D.; J. Sci. Food Agric. 2013, 93, 2084.

5. Dametto, A. C.; Agustoni, D.; Moreira, T. F.; Plaza, C. V.; Prieto, A. M.; Silva, T. G. A.; Souza, F. O.; Boralle, N.; Sorbo, J. M.; Silva, D. H. S.; Soares, C. P.; J. Funct. Foods 2017, 36, 490.

6. Chapla, V. M.; Biasetto, C. R.; Araujo, A. R.; Rev. Virtual Quim. 2013, 5, 421 .

7. Araujo, A. R.; Chapla, V. M.; Lopes, M. N.; Silva, D. H. S.; Cavalheiro, A. J.; Bolzani, V. S.; Planta Med. 2013, 79, PL38.

8. Jiang, M. Y.; Zhang, L.; Liu, R.; Dong, Z. J.; Liu, J. K.; J. Nat. Prod. 2009, 72, 1405.

9. Zhao, Y.; Si, L.; Liu, D.; Proksch, P.; Zhou, D.; Lin, W.; Tetrahedron 2015, 71, 2708.

10. MacroModel 9.1; Schrödinger, LLC, New York, 2015.

11. Frisch, M. J.; Trucks, G. W.; Schlegel, H. B.; Scuseria, G. E.; Robb, M. A.; Cheeseman, J. R.; Scalmani, G.; Barone, V.; Mennucci, B.; Petersson, G. A.; Nakatsuji, H.; Caricato, M.; Li, X.; Hratchian, H. P.; Izmaylov, A. F.; Bloino, J.; Zheng, G.; Sonnenberg, J. L.; Hada, M.; Ehara, M.; Toyota, K.; Fukuda, R.; Hasegawa, J.; Ishida, M.; Nakajima, T.; Honda, Y.; Kitao, O.; Nakai, H.; Vreven, T.; Montgomery Jr., J. A.; Peralta, J. E.; Ogliaro, F.; Bearpark, M.; Heyd, J. J.; Brothers, E.; Kudin, K. N.; Staroverov, V. N.; Kobayashi, R.; Normand, J.; Raghavachari, K.; Rendell, A.; Burant, J. C.; Iyengar, S. S.; Tomasi, J.; Cossi, M.; Rega, N.; Millam, J. M.; Klene, M.; Knox, J. E.; Cross, J. B.; Bakken, V.; Adamo, C.; Jaramillo, J.; Gomperts, R.; Stratmann, R. E.; Yazyev, O.; Austin, A. J.; Cammi, R.; Pomelli, C.; Ochterski, J. W.; Martin, R. L.; Morokuma, K.; Zakrzewski, V. G.; Voth, G. A.; Salvador, P.; Dannenberg, J. J.; Dapprich, S.; Daniels, A. D.; Farkas, O.; Foresman, J. B.; Ortiz, J. V.; Cioslowski, J.; Fox, D. J.; Gaussian 09, Revision A.02; Gaussian, Inc., Wallingford CT, 2009.

12. Bruhn, T.; Schaumlöffel, S.; Hemberger, Y.; Bringmann, G.; Chirality 2013, 25, 243.

13. Tung, T. T.; Jakobsen, T. H.; Dao, T. T.; Fuglsang, A. T.; Givskov, M.; Christensen, S. B.; Nielsen, J.; Eur. J. Med. Chem. 2017, $126,1011$. 
14. Stipanovic, R. D.; Wheeler, M. H.; Puckhaber, L. S.; Liu, J.; Bell, A. A.; Williams, H. J.; J. Agric. Food Chem. 2011, 59, 5351.

15. Voegtle, H. L.; Jones, T. H.; Davidson, D. W.; Snelling, R. R.; J. Chem. Ecol. 2008, 34, 215.

16. Senanayake, T. H.; Warren, G.; Vinogradov, S. V.; Bioconjugate Chem. 2011, 22, 1983.

17. Yuan, Y.; Tian, J. M.; Xiao, J.; Shao, Q.; Gao, J. M.; Nat. Prod. Res. 2014, 28, 278.
18. Forbes, J. E.; Pattenden, G.; J. Chem. Soc., Perkin Trans. 1 1991, 8, 1959.

19. Burrows, B. F.; Turner, W. B.; Walker, E. R.; J. Chem. Soc., Perkin Trans. 1 1975, 11, 999.

20. Fidanze, S.; Song, F.; Szlosek-Pinaud, M.; Small, P. L. C.; Kishi, Y.; J. Am. Chem. Soc. 2001, 123, 10117.

21. Turner, W. D.; Aldridge, D. C.; Fungal Metabolites, vol. I; Academic Press: New York, 1983.

Submitted: May 17, 2018 Published online: October 9, 2018 